\title{
Approaches to pre-modern war and ethics: some comparative and multi-disciplinary perspectives
}

Rory Cox

\begin{tabular}{|c|c|}
\hline Date of deposit & 08102018 \\
\hline Document version & Author's accepted manuscript \\
\hline Access rights & $\begin{array}{l}\text { Copyright (c) } 2018 \text { Informa UK Limited, trading as Taylor \& } \\
\text { Francis Group. This work is made available online in accordance } \\
\text { with the publisher's policies. This is the author created, accepted } \\
\text { version manuscript following peer review and may differ slightly } \\
\text { from the final published version. }\end{array}$ \\
\hline $\begin{array}{l}\text { Citation for } \\
\text { published version }\end{array}$ & $\begin{array}{l}\text { Cox, R. (2018). Approaches to pre-modern war and ethics: some } \\
\text { comparative and multi-disciplinary perspectives. Global } \\
\text { Intellectual History. Latest Articles. }\end{array}$ \\
\hline $\begin{array}{l}\text { Link to published } \\
\text { version }\end{array}$ & https://doi.org/10.1080/23801883.2018.1527709 \\
\hline
\end{tabular}

Full metadata for this item is available in St Andrews Research

Repository at: https://research-repository.st-andrews.ac.uk/

\section{St Andrews Research Repository}




\section{Approaches to pre-modern war and ethics: some comparative and multi-disciplinary perspectives}

War is both violent and significantly ordered. As an intrinsically social phenomenon, war is deeply affected by all manner of socio-cultural norms and 'ethics' that shape the conceptualisation and experience of war, from justifying it to condemning it, from formulating grand strategy to engaging in individual hand-to-hand combat, and from understanding what it means to achieve victory or suffer defeat.

How should we approach the study of war and the ethics of war, particularly from the perspective of intellectual history? When scholars still lack a consensus definition of what war is, much less a consensus about how war has shaped and been shaped by ethical thought, this is far from an easy question. I do not even dare to open this question up to 'violence' more generally, which expands the conceptual and definitional obstacles almost exponentially. ${ }^{1}$ The problem of definition is exacerbated when thinking across cultures as well as large expanses of time, for a definition that may appear suitable to describe ancient Near Eastern warfare may be inadequate to cope with sixteenth-century European warfare. A satisfactory universal definition becomes yet more elusive when thinking across disciplines, for the embedded interests of various disciplinary approaches will inevitably stress numerous differing elements that constitute the complex phenomenon of war, therefore generating contrasting definitions of what 'war' is.

For the purposes of this essay, I take war to refer to organised armed conflict between distinct and exogenously or endogenously recognised groups. This definition is broad enough to encompass most disciplinary interests in war and can also include civil wars, which are fought between competing groups who claim at least some degree of distinction and usually achieve some degree of exogenous or endogenous recognition. The definition is also narrow enough to preclude elements such as psychological, propaganda, or - in a contemporary context - cyber 'warfare' as independently meriting the identification of 'war'. According to my definition, a propaganda campaign alone is not sufficient to be defined as war. However, it fully admits that such aspects of hostility are very often integrated into wider armed conflict. Furthermore, while psychological and propaganda 'warfare' can certainly be detected in wars prior to the early-modern period (for instance, the terror tactics of Egyptian and Assyrian kings or the military advice of Sun Tzu), their development was quite rudimentary and their deployment limited. 
I do not claim to offer here anything like a methodological manifesto; rather, I simply offer some reflections on how different methodological approaches can inform a historical analysis of war and ethics. While I do not offer a concrete manifesto, I do admit to a personal scholarly conviction: a belief in the value of comparison. More contentiously, for any historian of a strictly historicist bent, I believe that a better understanding of pre-modern approaches to the ethics of war might teach us something about how we should think about the ethics of war today. Typically, we understand the historian as interested in empirical particulars, as opposed to the theorist, interested in abstractions and generalizations. Even without offering any value judgement, I think it is easy to exaggerate the distance between a historical interest in particulars and a theoretical interest in generalizations. ${ }^{2}$ I see no great distance separating them; I see no reason why the one cannot inform the other and vice-versa. History - however particular - undoubtedly has value for its own sake. But this conviction need not exclude the possibility that history may have different (not necessarily greater or lesser) value when incorporated into more generalizing explanations and theories, especially if those theories can help us to navigate the many challenges of our own contemporary world. It seems to me that no great mental effort is required to distinguish between an ambition to understand history wie es eigentlich gewesen, on the one hand, and a desire to employ historical evidence as something which might be deployed more generally, or provide guidance to contemporary challenges. The project of post-modernism has already shown us that the type of positivist objectivity envisioned by the likes of Ranke or Simiand is impossible. ${ }^{3}$ We simply need to have some self-awareness of where we are placing ourselves along the spectrum of relativism: are we striving for objectivity and contextual exactitude (knowing that we will never quite reach it), or are we willing to sacrifice a measure of contextual exactitude in order to service more generalizing and probably more presentist interests? As long as the scholar is honest with herself, and her reader, as to where along the spectrum she is residing when making any particular claim, then I see no great problem. Moreover, I believe it to be possible to occupy more than one position in a single study: using closely contextualised case studies, for example, but later drawing out the particulars of these case studies into more generalising theories.

Indeed, over the past five decades, much of the research on the history of the ethics of war, especially the Western just war tradition, has been completed by scholars with a pronounced interest in normative thought. While a historical interest and approach clearly informs their work, such scholars have frequently hailed not from history faculties but from faculties of religious studies or philosophy. Some philosophers - most notably Michael 
Walzer and Anthony Coates - have adopted a 'cherry-picking' approach to historical examples as a way to ground their normative assertions. ${ }^{4}$ Other ethicists have embarked on a far more rigorous analysis of developments in historical thought. ${ }^{5}$ More recently, the torch has predominantly been passed to scholars ensconced within the broad field of International Relations, whose engagement with normative theory in the realm of military ethics is nonetheless informed by an increasingly sophisticated historical awareness. ${ }^{6}$

\section{The value of comparison}

What do I mean by comparison, or rather, a comparative methodology? Within the realm of comparative history, Marc Bloch put it thus:

Without any doubt it means this: he [the historian] selects two or more phenomena which appear at first sight to be analogous and which occur in one or more social milieus. He finds out how these phenomena resemble or differ from one another, traces their evolution, and, as far as possible, explains the similarities and differences. ${ }^{7}$

In the early twentieth century, Bloch considered the 'perfection and general use' of the comparative method as 'one of the most pressing needs of present-day historical science. ${ }^{8}$ In asserting this claim, Bloch was reacting to a professional discipline that was becoming ever more specialized and narrowly focused, both in terms of chronological range and geographical focus. Some historians have perhaps been more inclined towards this tendency than others. Scholars of the American Civil War, for example, unabashedly carry the torch of hyper-specialization, generating monographs such as: Pickett's Charge: A Microhistory of the Final Attack at Gettysburg; or Gettysburg: The Second Day. ${ }^{9}$ In contrast, historians of the European early middle ages, for example, have often been required to look at broad chronologies or expansive geographies simply as a matter of necessity: the source base, or rather lack of it, not permitting a microscopic focus on one day, one year, one decade, or sometimes even one century.

I maintain that a willingness to look at historical subjects comparatively is intrinsically a good thing. Without a comparative perspective it becomes much harder to appreciate fully the uniqueness or generality of phenomena, or to judge their importance, in relative or absolute terms.

Bloch stipulated that the comparative method required two conditions: 'a certain similarity or analogy between observed phenomena... and a certain dissimilarity between the 
environments in which they occur.' ${ }^{10}$ War seems particularly well suited to such a comparative project. It is observable in almost every known human society and environment, from very early nomadic or pastoralist societies to highly industrialised and technologically advanced modern societies. Yet the core phenomena remain consistent - that is, people deliberately wound and kill one another and destroy property in order to achieve their ends, whatever they may be. Nonetheless, Bloch's stipulations for comparative methodology seems overly restrictive. Most obviously, a comparison of similar environments that produce different phenomena seems equally as valid as Bloch's model of similar phenomena produced in different environments. Bloch also preferred comparison between societies that were historical contemporaries and geographically proximate, believing that such comparison was 'more precise' than the typically 'hypothetical conclusions' generated by the 'grand manner' of comparing 'societies far removed from one another in time or space'. ${ }^{11}$ However, Bloch provides no convincing argument for his preference for comparing geographically and chronologically proximate societies. As Sewell observes, '[m]ere temporal and spatial proximity...does not assure similarity, and some societies which are very remote from one another are surely more alike, at least in ways that are crucial for some explanatory problems, than some neighbouring societies'. ${ }^{12}$

The real question is whether we are utilising 'appropriate units of comparison'. Are we comparing like with like, or are we wilfully misinterpreting the phenomena of one society in order to mould them into something they are not - something that would be unrecognisable to the members of that society? Likewise, are we really tracing the development of similar phenomena across societies through lines of influence and transmission, or are we simply discovering parallel but unrelated developments? In something so universal as war, this concern is especially pertinent. War is evident in almost every society, regardless of time or space. The odds are favourable that certain phenomena linked to war have occurred, or will occur, in more than one society; we must be cautious before we assign historical relationships between such phenomena, whose existence in more than one society may be purely accidental, and whose creation may be a result of very different assumptions and processes.

Nevertheless, the existence of very similar social norms and practices in multiple societies with no established lines of communication is a significant insight in itself, for it might hint at general causes. In the realm of the ethics of war, such insights are particularly interesting. If it can be established that societies develop similar ethical responses to the similar existential threats and remarkable opportunities created by war, then perhaps we will come as close as we are ever likely to come to a genuine insight about human nature, if such 
a thing exists. For, as Freud observes, war is such an extreme activity that it 'strips us of the later accretions of civilization, and lays bare the primal man in each of us. ${ }^{, 13}$

Notwithstanding his enthusiasm for comparative history, Bloch believed that comparison was most useful for highlighting the idiosyncrasies and fundamental uniqueness of individual societies, not for highlighting their similarities. ${ }^{14}$ For Bloch, relativism rather than universalism was at the heart of the comparative approach - a stance also championed by Clifford Geertz, who has eschewed anthropological claims to discover a consensus gentium (universal human customs) and instead lauds the values of cultural oddities. ${ }^{15}$ The capacity of a comparative approach to broaden the historian's horizons is also noted by Chris Wickham, who views comparison as essential to avoiding cultural solipsism: 'if you don't compare, you end up believing that one type of historical development is normal, normative, and that every other is a deviation'. ${ }^{16}$ Wickham makes the astute observation that scholars who do not engage in comparative study typically study their own country, which frequently leads to insularity and further engrains national teleologies. Indeed, comparison may be inherently threatening to entrenched social values, for in comparing one pattern of morals and customs to another, groups may open themselves up to the possibility that 'their own morals and customs may not be right, sacred, or universal - as they are generally held to be'; ${ }^{17}$ consequently, such 'threats' are either stigmatised, trivialized, or alienated. Arguably, scholars of war and violence might consider it a duty to embrace this threatening methodology and employ it to challenge prevailing social norms or social apathy concerning something as terrible as war.

The utility of studying war and ethics over the longue durée, between multiple cultures and different geographical areas, lies in an assumption that such a project can highlight not just the differences between these societies, but also perhaps their similarities. It may shed light how different societies approached the problem of war in very similar ways, and how certain strains of ethical and legal thought were adopted and adapted between these societies as a result of their cultural, political, and military interaction. Of course, these are contentious claims in and of themselves. According to Bloch, positing that different societies reached similar approaches or solutions to the problems they encountered suggests the existence of 'the fundamental unity of the human spirit or, if you wish, the monotony and astonishing poverty of human intellectual resources during the course of history.' ${ }^{18}$

I am not convinced of this. The adoption and adaptation of ideas across time and cultures need not imply a single human 'nature', nor a poverty of human intellectual resources. One can just as easily argue that it simply demonstrates that, as social animals, 
humans recurrently encounter certain facets of social life that are fundamentally important yet challenging at the same time. The expression and practice of concepts such as justice, security, love, friendship, order, and trust (the list could go on) recur in differing but analogous forms in almost every society. Arguably, this is because the norms and behaviour associated with such concepts are crucial for successful communal living, especially as communities become larger and more complex. If one accepts that human societies are faced with a series of challenges that are directly comparable across space and time - how to secure resources, how to guarantee a sufficient degree of internal order, how to maintain external security - then it should come as little surprise that societies have, at least occasionally, created similar solutions. ${ }^{19}$ Nor should it be surprising that successful solutions and practices have been borrowed across societies, whether as a consequence of direct interaction as a result of economic trade, political relations, or military conquest, or indirect interaction, such as through inherited customs, laws, religion, or even through historical study of the past. As Sorabji and Rodin note, 'different traditions are not hermetically sealed from each other'. ${ }^{20}$ Indeed, it is through comparison that we are best able to detect influences and even continuities across socio-cultural borders. ${ }^{21}$

The issue of borders is itself fraught with interpretative problems. Comparison is most often made between societies, which we tend to distinguish as distinct states and identify according to geographic borders. War, by its very nature, makes a mockery of such geographic borders. Firstly, if understood as a contest between states or distinct political communities, war frequently breaks down old territorial borders and throws up new ones in its wake. Secondly, military conquest of a territory does not usually constitute the simple expansion of the victorious society and the complete removal or eradication of the defeated (although such an eventuality has occurred in the past, especially in the ancient Near East); rather, the victorious society often subjugates and governs the new territory, leaving its preexisting social structure and culture largely intact. Over time, this results in a process of acculturation. In other words, an apparently rigid political-geographical border need not imply a rigid socio-cultural border. At borders between states or communities, especially those in flux, there are myriad ways in which social and cultural lines can become blurred. This blurring operates in times of peace as well as in times of war. ${ }^{22}$

\section{Purpose of the comparative method}

In adopting a comparative approach to war and ethics, four questions seem to stand out as particularly important: 
1) When does ethical reflection on war first emerge?

2) Why does ethical reflection on war emerge?

3) Do different systems of ethics concerning war express distinct or similar ideas?

4) How does ethical reflection on war influence the actual conduct of wars? ${ }^{23}$

Underlying these questions is the assumption that societies were fighting wars for generations before any identifiable or coherent 'ethics of war' emerged. As Bernhard Williams posited, in the beginning was the deed, not the word or the belief. ${ }^{24}$ Similarly, Freud asserted that mankind's speculative endeavours were only initiated as a result of experiencing the death of loved (yet hated) persons. ${ }^{25}$ It would also appear outlandish to claim that any system of military ethics - past or present (or future?) - is morally autonomous in the Kantian sense: i.e. sprung from universal duties rather than desires. Ethics of war service the needs of particular war societies and warriors, not the duties of a universal morality. This does not mean that such ethical systems are entirely permissive or are purely a veil for hardnosed realism. Over the course of history, societies and warriors have displayed a consistent desire to perceive themselves as 'good', 'righteous', and 'just'; as a result, they are perfectly capable of imposing limits and penances on themselves in order to satisfy idealistic demands. After all, without some principle of justice or restraint to govern human relationships, it is difficult to imagine how any community could long survive, let alone prosper. Communities simply could not exist if a majority of individuals indulged in unrestrained violence; as St Augustine pointed out, there is honour even among thieves.

Clearly, ancient communities flourished as a result of successfully developing ethical and behavioural norms designed to limit and regulate the internal use of violence in order to maintain the stability of the community. The earliest surviving legal codes seek to restrain and regulate intra-communal violence, while modern psychological research suggests that human beings possess an innate aversion to killing other members of their species. ${ }^{26}$ However, communities also needed to reconcile these violence-limiting norms with the occasional (or perhaps frequent) requirement to employ extreme violence against competing communities. The quotidian aversion to violence within the community thus had to be replaced by an acceptance of large-scale violence for the extra-communal activity of war. This inversion of ethical and legal norms was necessary for the survival or expansion of a community; nevertheless, as an inversion of 'normal' morality and behaviour, it required explanation and legitimation. The fruit of this process of explanation and legitimation is what is referred to as the ethics of war. 
Therefore the ethics of war emerged from the crucible of war and were shaped by its exigencies and realities. Societies and individuals frequently want to engage in war, and thus require ethical systems that permit them to pursue war whilst minimizing any risk to their self-image as 'righteous' and 'good' according to the definitions of their own community. Such systems can also serve the function of imposing restraints that allow for the possibility of a modus vivendi to be re-established with competitors (enemies) after the war is finished or encouraging conduct that provides a measure of security for all antagonists - enslavement or ransoming versus summary execution; the preservation of types of agricultural or sacred property, etc. - and might therefore be interpreted as a form of insurance policy. As such, restraint performs a pragmatic function despite being imagined through an idealistic lens, and further reinforces the warrior's self-image as a righteous individual belonging to a righteous (ergo superior) society.

\section{Anthropological Approach}

I have discussed the basic premise of the comparative approach from a historical perspective. It is time to turn now to a consideration of how other disciplines can aid our investigation of war and ethics. The most significant contribution of anthropology is to our understanding of culture and its multi-layered complexities and meanings. War is an essentially communal, social, and cultural phenomenon; therefore, the scholar interested in war can benefit from anthropological insights.

Anthropologists have typically been most interested in explaining the existence of war in societies and how it is fought. These observations are used as a means to better understand the human relations and layers of meaning that make up the culture as a whole. Even more fundamentally, war is seen 'to play a central causal role in the general evolution of cultural systems' ${ }^{27}$ Very roughly, we can divide anthropological thought on war into two camps: structuralists and superstructuralists. Structuralists emphasise material causes and factors, and leading lights of this approach (so-called structural functionalists such as Malinkowski and Radcliffe-Brown) have been hostile to historical perspectives. ${ }^{28}$ In reading structuralist/materialist analyses of war, there seems little to differentiate between materialism and political realism (or pragmatism). By citing material interests as the primary and sometimes sole cause of war, structuralists not only support the idea that all humans are essentially motivated by the same thing (wealth, power, prestige - or 'ophelimities' as Andreski terms them ${ }^{29}$ ), but also effectively reject the central importance of ethics, religion, 
or any other ideational influence. ${ }^{30}$ How one explains wars such as the Crusades, then, becomes difficult, unless one is willing to fall back on now out-dated views that the crusades were simply about second-sons seeking their fortune. Equally, how might one explain the famous Melian resistance against Athens, when armed resistance was so obviously doomed to failure $?^{31}$ Why do societies repeatedly limit their actions in war, if nothing drives them other than a desire for resources and power? One might turn to the 'insurance policy' explanation (that societies restrain themselves on the understanding that others will follow suit), but it seems that this explanation is having to do a lot of work to explain away the ethics of war entirely. A rigid structuralist approach also ignores the extensive anthropological work completed on taboo, which establishes that societies frequently understand war and killing (even if necessary to protect the community) as problematic. ${ }^{32}$ If killing in war was simply about resource/power acquisition or defence, it is difficult to explain the existence of widespread taboos on warriors who have successfully defended or acquired such resources/power. (And we should certainly think of the doctrine of penance in the medieval Christian world as a clear example of taboo.) Finally, ground-breaking recent work on the role of emotions and honour in international relations surely adds an important new dimension to any discussion of material versus non-material interests as causes of war. ${ }^{33}$

This is not to say that structural conditions do not influence war: they are clearly crucial, and in many cases war can and should be seen as primarily a competition for resources or power. The structural, or infrastructural conditions will influence how a war is waged, ${ }^{34}$ and they will also influence the creation of ethics and laws pertaining to war, for the ethics of war must inevitably reflect the physical practice of war, at least to some extent. For example, a pastoralist society is unlikely to develop norms protecting crops or fruit trees during wartime, whereas an agriculturalist society is more likely to do so (e.g. Deuteronomy 20).

Superstructuralists, by contrast, emphasise the role of culture in determining why and how societies fight, with many arguing that war is a cultural invention, governed by social customs and conventions. This superstructural approach has generally been more receptive to historical perspectives. ${ }^{35}$ An extreme, albeit now virtually abandoned, emphasis on the fundamental role of culture in the origin and development of warfare was evident in so-called 'diffusionist theory', with some scholars going so far as to pinpoint the actual invention of war in predynastic Egypt (early third millennium BCE), from whence it was exported to other world cultures. ${ }^{36}$ 
A modified version of the superstructural approach was pioneered by Clifford Geertz, who encourages us to look at culture as a web of symbols, each with its own distinct but interdependent meaning:

The concept of culture I espouse...is essentially a semiotic one. Believing, with Max Weber, that man is an animal suspended in webs of significance he himself has spun, I take culture to be those webs, and the analysis of it to be therefore not an experimental science in search of law but an interpretive one in search of meaning. It is explication I am after, construing social expression on their surface enigmatical. ${ }^{37}$

Geertz's interest in the meaning and social import behind structures of signification is particularly apposite to questions of war, violence, and ethics. This is because war involves actions that are usually prohibited within the domestic sphere and yet, through a process of ethical reasoning, are made acceptable. In most pre-modern societies, if a person ran a sword through someone else in the course of normal daily life then it would be accepted that that person had committed a crime; as a result, the actor would likely face severe punishment or risk initiating a blood feud. However, if that same actor ran a sword through a member of a rival community during 'war time', not only would that person be excused from punishment (although not necessarily taboo/penance), but s/he would even be lauded and rewarded for the killing. What accounts for the different consequences? It is that the actions, though physically identical, have different meanings and significance. Only by understanding the nuances of the structures of signification within the prevailing culture can we begin to interpret these meanings and thus gain a better understanding of how any specific society distinguishes illicit murder from licit killing.

In terms of methodology, how are we, as historians, to proceed? Anthropological methodology is most renowned for deep field research, with the anthropologist embedding $\mathrm{him} /$ herself in a society and observing the minutiae of everyday life, which hopefully enables a thick description of a society's behaviours and their context. Clearly, such fieldwork is not possible for historians of pre-modern societies, and we must instead rely on textual or material artefacts. Nevertheless, there is much to be learned from the anthropological approach and its interest in minutiae and meaning. Historians are very often likes magpies, drawn to the shiniest evidence, whether literary or archaeological. But this can distort the image of a historical society. By their very nature, shiny things are unusual and special, they are rarely representative of the typical and quotidian. Through utilizing as wide a range of 
evidence as possible and paying attention to historical minutiae - those dull or fragmentary texts, those cracked or lacklustre pottery shards - the historian will be better able to reconstruct a historical culture in the round and get closer to the webs of significance suggested by Geertz, whilst also conceding that such webs will always remain fundamentally elusive to the scholar. ${ }^{38}$ Carlo Ginzburg spoke of something similar when he proposed that historians should follow the method of Giovanni Morelli, Sherlock Holmes, and Sigmund Freud, tracking down tiny details or 'spie' (clues) in order to reveal 'a deeper reality'. ${ }^{39}$ Of course, the twentieth-century turn to social and cultural history, away from the history of 'great men', has already contributed to this more holistic approach to the past. The same trend is also evident within intellectual history, with the 'linguistic turn' of the Cambridge School championing a methodological approach prioritising the recreation of a detailed linguistic context for works of political thought. ${ }^{40}$

There is an important caveat to be made. The anthropological approach must distinguish between culture as a reality and culture as a subject of analysis. As Geertz says, descriptions of particular cultures are 'constructions we imagine...[people] to place upon what they live through, the formulae they use to define what happens to them. What it does not mean is that such descriptions are themselves...part of the reality they are ostensibly describing. ${ }^{41}$ This is even more obvious when analysing the historical past. The very process of attempting to reconstruct ethical systems of thought about war undoubtedly produces distortions and divergences from historical 'reality'. What I mean by this is that my articulation of an ethical system of thought requires a significant degree of organization, explanation, and coherency in order to make it intelligible to the reader. But this level of coherency likely goes beyond the articulation of the customs and norms of the particular society under examination. Most social conventions are based on cultural assumptions and adopted behaviours; in other words, people may not have thought about such things very much, all the while having their actions shaped by them. To refer to an ancient Egyptian or ancient Greek 'ethics of war', therefore, may be somewhat artificial, in that it infers a formal, monolithic system. The reality was probably something more nebulous and pliable. Examining military and political history is perhaps the best way to infer whether these ethical systems found some sort of coherent and concrete expression. On the other hand, the realisation that culture is itself rarely free from contradictions - something highlighted by anthropology $y^{42}$ - is a crucial step in better understanding the complex relationship between the ethics of war and the conduct of war. Military conduct frequently contravenes ethical or 
legal norms, but this does not necessarily mean that such norms or laws are defunct, or that people do not hold them dear.

Indeed, one further facet of Geertz's approach to culture can highlight the value of investigating the ethics of war rather than the strategic, tactical, or technological aspects of military history. Geertz proposes 'that culture is best seen not as complexes of concrete behavior patterns - customs, usages, traditions, habit clusters - ...but as a set of control mechanisms - plans, recipes, rules, instructions (what computer engineers call "programs") for the governing of behavior...man is precisely the animal most desperately dependent upon such extragenetic, outside-the-skin control mechanisms, such cultural programs, for ordering his behavior. ${ }^{43}$ Viewed from this angle, ethics of war - as sets of rules and instructions, or control mechanisms - are more fundamental to understanding war in any particular society than the 'concrete behaviour patterns' of waging war itself.

\section{Sociological Approach}

War is a social phenomenon, and the ethics of war are a product of collective thought. More than any other discipline, sociology has thought systematically about the nature of social relations, groups, and institutions. In their approach to war, most sociologists treat it as directly comparable with other types of conflict, whether within the family or between socioeconomic classes. As a product of social factors, they eschew the socio-biological ideas espoused by some anthropologists, which attempt to ground war in human biology, instincts, and 'nature'. According to Hans Speier, the specific character of war 'is dependent upon the specific organization of society and times of peace... any aspect of war is fully intelligible only when it is seen in relation to the given organization of those societies, their technologies and their institutions, their material resources and their morals. ${ }^{44}$ Indeed, sociologists often credit war with strengthening the bond between members of a group, therefore see its development as a social response to perpetuate communal life. ${ }^{45}$ For those interested in the ethics of war this has real relevance, because it posits that the physical characteristics of war are forged by social forces that include social morals, and that such forces have a determinative or constitutive quality in how wars are prosecuted. This stands in stark contrast to Clausewitz's claim that, when defining war, the existence of 'certain self-imposed' ethical restraints in the form of international law and custom are 'hardly worth mentioning' and 'lead to logical absurdity'. ${ }^{46}$

Of further pertinence to the relationship between ethics and war is Émile Durkheim's insistence that social facts are 'real' and should be considered as 'things'. As Durkheim 
(1982: 43, 59) describes, 'We represent them [social facts] as consisting of manners of acting or thinking, distinguishable through their special characteristic of being capable of exercising a coercive influence on the consciousness of individuals. ${ }^{47}$ Social phenomena are, therefore, external to individuals and are generated only through the interactions of a combination of individuals - a society - rather than from a single individual alone:

this synthesis sui generis, which constitutes every society, gives rise to new phenomena, different from those which occur in consciousnesses in isolation...these specific facts reside in the society itself that produces them and not in its parts - namely its members. In this sense therefore they lie outside the consciousness of individuals as such, in the same way as the distinctive features of life lie outside the chemical substances that make up living organism. ${ }^{48}$

Evidence for this psychological distinction between groups and individuals could be found in the fact that the mentality of groups is not the same as individuals and therefore collective consciousness was subject to different laws than individual consciousness. This collective consciousness inevitably produced new social facts, which Durkheim termed 'institutions' ${ }^{49}$

According to this reasoning we should consider war - as a social enterprise - as reflective not of individual but collective consciousness. More than that, war itself becomes an institution, with an existence independent of the individuals who partake in it. The morality or ethics of war, consequently, must also be a product of the group rather than the individual, and as such, we should expect that the ethics of war favour the interests of the group over the interests of the individual. How might this affect their content and direction? Might the collective conscience that produces the ethics of war countenance action at which the individual conscience might baulk? We might find this rather worrying, as Durkheim was sure that individuals were subjected to social facts/institutions 'without being able to modify them' 50

One consequence of this insistence that social facts are 'things' was Durkheim's faith in positivism and his belief that the scholar could observe social facts free from influences of his/her own circumstances. ${ }^{51}$ Given Durkheim's faith in the objectivity of positivism, he was also willing to assess different systems of ethics as normal or pathological 'on the basis of empirical examinations of the appropriateness of the rule to its social context' ${ }^{52}$ This would imply that not only can we accurately reconstruct ancient and medieval systems of ethics, but that we can even judge them to be 'normal' and 'pathological', or 'good' or 'bad'. But can 
we really claim that certain rules, limitations, or justifications of war become 'pathological' or 'bad' when they no longer reflect the dominant social conditions? By contrast, Max Weber warned that empirical science should not confuse $i$ s with ought, thus necessitating a rejection of Durkheim's confidence of engaging in normative judgements. ${ }^{53}$

Another response to Durkheim's positivism is the argument that by identifying 'systems' or 'traditions' or 'schools' of thought (ethical or otherwise), we are in fact creating something like an ideal type: an instrument of analysis and interpretation and nothing more. As Terry Nardin argues, a tradition or system of thought "is not a "thing," an ontologically given object of perception, a natural kind. The idea that there is a fixed and objective roster of ethical viewpoints waiting be correctly identified is absurd. ${ }^{54}$ Weber, of course, coined the term 'ideal type' and did much to promote its use an analytical tool. ${ }^{55}$ The historian of the ethics of war can greatly benefit from this tool. Three conceptual categories are particularly invaluable in crafting an intelligible analysis of thought on war in different societies. These 'ideal types' are: 1) just cause; 2) proper authority; 3) correct intention. Added to these are the broader categories of ius ad bellum and ius in bello. These categories are basically a product of the Romano-Christian just war tradition, the first two being discussed by Cicero and other pre-Christian writers, the third being introduced by Christian thinkers such as St Ambrose of Milan and St Augustine of Hippo. However, it wasn't really until the twelfth century that the three categories were systematically delineated. ${ }^{56}$ To apply these categories to ancient Near Eastern ethical and legal thought is therefore patently anachronistic and requires a level of abstraction. Nonetheless, treated as 'ideal types', and used as an organizing analytical instrument, these categories are extremely useful. For, while Egyptians or Hittites never possessed the technical language of 'just cause' or 'proper authority', they undoubtedly possessed ideas analogous to these concepts. Furthermore, their ideas bear direct comparison to later just war theories, where the language of cause, authority, and intention is explicitly articulated. ${ }^{57}$ This is why, as ideal types, these categories can be used to organise and then compare cultures of war separated not only by language, but by significant expanses of time and space. After all, as Quincy Wright noted in his magisterial interdisciplinary study of war, 'Fictions, while necessary in the natural sciences, are the essence of the social sciences. The social scientist must create a structure of assumptions and use a language which is at the same time symbolic and emotive.' 58

\section{Psychological Approach}


Finally, I would like to consider the benefits of psychological analysis to the historical study of war and ethics. In many ways, integrating a psychological approach poses the greatest challenge to the historian, for few would dare to claim that we can accurately comprehend the psychology of historical actors merely through the words or objects they have left behind. Historical sources are, at best, deliberate constructions that present a one-sided record or interpretation of events; at worst, they are deliberate attempts to mislead and invent an alternative history that in no way reflects historical reality.

Nonetheless, since the time of Homer, writers of war have been interested in the psychology of warriors. ${ }^{59}$ Indeed, Simone Weil famously argued for the importance of force and power as fundamental drivers of human psychology that underlie the themes of the Iliad.$^{60}$ Freudian psychoanalysis has also been interested in the relationship between the destructive and sociable impulses in human psychology, and the affect this has on internal and external social relations. Like anthropological superstructuralists and most sociologists, psychologists tend to view war as essentially controlled by social customs and institutions. ${ }^{61}$ However, this is not to say that war is not also rooted in deep psychological impulses, neuroses and desires. At least one psychoanalytical approach seeks to root war largely in individual psychology rather than 'social facts' or materialism. ${ }^{62}$ This approach claims that 'war represents a social institution the aim of which is to cure the paranoid depressive anxieties existing (in no more or less marked degree and more or less resolved in terms of integration with reality) in every man'. ${ }^{63}$ War transforms a psychologically internal enemy the "Terrifier" - into 'an external, flesh-and-blood adversary who can be faced and killed'. ${ }^{64}$ As such, war helps individuals maintain psychological equilibrium. Fornari goes as far to suggest that:

war could be seen as an attempt at therapy, carried out by a social institution which, precisely by institutionalizing war, increases to gigantic proportions what is initially an elementary defensive mechanism of the ego in the schizo-paranoid phase.... The most enigmatic aspect of this system would seem to be its desire to control the uncontrollable by translating internal psychotic anxieties into real external dangers. ${ }^{65}$

If war functions to enhance both internal psychological and external physical security, then this may explain why war has been so prevalent. While the proposition that war is a form of therapy might sound a little outlandish, the theory that war was an outlet for repressed impulses was proposed by Freud many years earlier. If true, this would seem to suggest that 
war is essentially unrestrainable (itself being a product of unrestrained impulses), and therefore normative claims associated with the ius in bello tradition are merely illusory - as Clausewitz maintained.

Pursuing a slightly different tack, others have sought to explain the near universalism of war - regardless of different social contexts - in the fact that war 'promises to fulfil some need or combination of needs that are at least close to universal....We are dealing here with what is clearly a fundamental human tension'. ${ }^{66}$ This tension is the specifically human experience of asserting individualism at the same time as attempting to integrate as a member of a group. War has been the most common method of alleviating this tension, although mysticism is an alternative. ${ }^{67}$ Promising to enhance individual prowess while at the same time deeply integrating the individual into a cohort united by shared (traumatic) experiences, war is potentially very attractive; however, for many, this attraction is difficult to admit. ${ }^{68}$ Building on LeShan's hypothesis, I would speculate that the ethics of war help to persuade us that the things which we guiltily desire (war and violence, and the potential profits associated with them) are not really so bad; indeed, these guilty desires can be made into something positive. Everyone would like to be told that their bad habits are virtuous. The truth, after all, is that communities and states cannot go to war without the participation of individuals, while an individual cannot make war without a larger community or state. We cannot place guilt or blame solely on the shoulders of the community or on the shoulders of the individual when both are complicit in war-making. ${ }^{69}$ It is to this truth that Henry V speaks in Shakespeare's play when, disguised before the battle of Agincourt, he argues with his soldiers that 'Every subject's duty is the King's, but every subject's soul is his own' ${ }^{70}$

Freud's thought on war very much focused on this relationship between the state/society and the individual. Freud suggested that society seeks to curb the basic impulses of violence possessed by all individuals, through enforcing social customs, mores, and morality. The motivation for doing so, however, is not to eliminate violence per se, but rather to monopolize its use to the state. ${ }^{71}$ Responding to the horrors of World War 1, Freud declared: 'A belligerent state permits itself every such misdeed, every such act of violence, as would disgrace the individual. ${ }^{72}$ The danger of war is that, through encouraging its citizens to indulge in violence that is usually denied to them in normal society and morality, the state actually destroys the dams constructed by social influences during a person's lifetime, dams that are intended to curb individual violent impulses. The result is a flood of unrestrained violence that strikes normal society as immoral and atrocious: 
Nor should it be a matter for surprise that this relaxation of all the moral ties between the collective individuals of mankind should have had repercussions on the morality of individuals; for our conscience is not the inflexible judge that ethical teachers declare it, but in its origin is "social anxiety" and nothing else. When the community no longer raises objections, there is an end, too, to the suppression of evil passions, and men perpetrate deeds of cruelty, fraud, treachery and barbarity so incompatible with their level of civilization that one would have thought them impossible. ${ }^{73}$

As the psychoanalyst Robert Laing might put it, war is an assault on the established routines, norms, and expectations that together create an individual's 'ontological security': that is, the secure identity of the 'self', which empowers individual agents with personal agency. As Anthony Giddens has shown, this sense of the 'self' can equally be applied to societies and states. ${ }^{74}$ War so blatantly violates everyday norms and routines that it threatens to undermine the self-image of the individual or society, creating 'ontological insecurity'. War breaches the psychological dams, so to speak, which social individuals have spent a lifetime building in order to control the waters of their violent proclivities. Arguably, the ethics of war are an attempt to patch breaches in these dams (caused by war itself) by claiming that war is still governed by morality and rules that are derived from everyday morality and routines, albeit adjusted according to the unique realities of war. Ethics of war tell us that justice, righteousness, piety, and so on, are all to be found in war, as in peace. For the warrior, this provides some measure of ontological security and makes a return to society, after war, possible.

Indeed, the declaration of war arguably entails a psychological reordering of sorts, inaugurating a 'new psychological world established by war'. ${ }^{75}$ Rituals governing the declaration of war, such as the Roman practice of hurling a javelin into enemy territory (later symbolically represented in the Forum), inform the warrior that normal morality has ceased and a temporary morality - which permits homicide, pillage, arson, rape, and enslavement has been instituted. During war itself, the ethics of war perform a critical function for the individual combatant, assuaging the guilt associated with warlike actions and the inversion of normal morality. They are also useful to combatants who, embedded in theologies that teach that one's experience of the afterlife is dependent upon one's virtuous actions in life, may be anxious by the increased chance of death brought about by war itself. Moreover, with traditions of war often stressing the self-sacrifice of the warrior, individuals could assuage their guilt by justifying it on the basis of defending loved persons and homeland, perhaps 
even appealing to masochistic psychological impulses. We are quick to disparage the sacrifices of others for values we perceive as worthless as the actions of the masochist or the sadist, whereas extreme sacrifices for values that we ourselves approve of are interpreted as acts of heroism or sanctity. ${ }^{76}$ Indeed, if the ethics of war genuinely puts combatants of one side at a disadvantage (through limiting their violence), this too could be interpreted as evidence of a masochistic streak within a certain society, perhaps assuaging a deeply felt guilt at engaging in war in the first place.

The problem, argues Freud, is that the moral rules of society, which constrain natural impulses, force individuals to act psychologically beyond their means. ${ }^{77}$ Society produces cultural hypocrites. It is not surprising that in extreme circumstances such as war the removal of the strict social rules produces a range of actions that most people would deem horrific and immoral. ${ }^{78}$ Put simply, war destroys cultural instinct training. ${ }^{79}$ The ethics of war, therefore, can be seen as an attempt to keep the damage to a minimum.

\section{Conclusions}

Much more could be said about the methodologies of the aforementioned social sciences, not to mention disciplines such as analytical philosophy, theology, art history, geography, International Relations, and others which have not been discussed. I have simply suggested some avenues for thought, although I am painfully aware that I have been far from comprehensive and have indulged in a good deal of speculation.

The issue I have not addressed, but arguably should have made a priority, is why we should study war or the ethics of war in the first place.

Scott Davis claims that the "ways in which peoples have justified and constrained the use of...force are windows into how they see themselves and the other peoples with whom they share, often reluctantly, the world around them. ${ }^{80}$ The reason why war and the ethics of war are especially revealing about the character of certain societies is because it is only in times of uncertainty, anxiety, and change that people really question the relationship between their beliefs and values, on the one hand, and their actions, on the other. ${ }^{81}$ The study of war and the ethics of war encompasses the entire gamut of human experience: individual and group psychology, religious belief, art and technology, philosophical enquiry, jurisprudence, the role of institutions, economic costs and benefits, international politics, life and death. I would suggest that we learn more about a society from its justification and practice of war than from any other aspect of its history, for the very reason that war and the ethics of war are informed by, and also inform, so many other social practices and beliefs. Furthermore, one 
can argue that it is only in the extreme that one sees the true character of a society. Under stress and existential threat, what are the values that a society clings to, and what is jettisoned as superfluous? These are fundamental questions and may provide fundamental insights. It is only by learning from the many discoveries of other disciplines that we can begin to ask the right questions of our material, and hopefully provide some compelling answers.

\section{Bibliography}

Andreski, Stanislav. Military Organization and Society. $2^{\text {nd }}$ edn. London: Routledge \& Kegan Paul, 1968.

Bederman, David J. International Law in Antiquity. Cambridge University Press: Cambridge, 2001.

Bellamy, Alex J. Just Wars: From Cicero to Iraq. Cambridge: Polity Press, 2006.

Bloch, Marc. "Toward a Comparative History of European Societies.” In Enterprise and Social Change: Readings in Economic History, edited by Frederic C. Lane and Jelle C. Riemersma, 494-521. Homewood, IL: Richard D Irwin, 1953.

Bonner, Michael. Jihad in Islamic History: Doctrines and Practice. Princeton and Oxford: Princeton University Press, 2008.

Brekke, Torkel, ed. The Ethics of War in Asian Civilizations: A Comparative Perspective. London: Routledge, 2006.

Brown, Warren C. Violence in Medieval Europe. New York: Longman, 2011.

Clausewitz, Carl von. On War, edited and translated by Michael Howard and Peter Paret. Princeton: Princeton University Press, 1984.

Coates, Anthony J. The Ethics of War. Manchester and New York: Manchester University Press, 1997.

Cox, Rory. "Expanding the History of the Just War: The Ethics of War in Ancient Egypt." International Studies Quarterly 61, no. 2 (2017): 371-84.

—. "The Ethics of War up to Thomas Aquinas." In The Oxford Handbook of Ethics and War, edited by Seth Lazar and Helen Frowe, 99-121. New York: Oxford University Press, 2018.

_. "Gratian." In Just War Thinkers: from Cicero to the $21^{\text {st }}$ Century, edited by Cian O’Driscoll and Daniel Brunstetter, 34-49. London and New York: Routledge, 2018. Crawford, Neta C. "The Passion of World Politics: Propositions on Emotion and Emotional Relationships.” International Security 24, no. 4 (2000): 116-56. 
—_. "Emotions and international security: Cave! Hic Libido." Critical Studies on Security 1, no. 1 (2013): 121-3.

_. "Institutionalizing Passion in World Politics: Fear and Empathy." International Theory 6, no. 3 (2014): 535-57.

Davis, G. Scott. "Introduction: Comparative Ethics and the Crucible of War." In The Ethics of War in Asian Civilizations: A Comparative Perspective, edited by Torkel Brekke, 136. London: Routledge, 2006.

Durkheim, Émile. The Division of Labor in Society, translated by George Simpson. Glencoe, Il., 1949.

—. The Rules of Sociological Method, edited with an introduction by Steven Lukes, translated by W. D. Halls. New York: The Free Press, 1982.

Ferguson, R. Brian. "Explaining War.” In Anthropology of War, ed. Jonathon Haas, 26-55. Cambridge, New York, Melbourne: Cambridge University Press, 1990.

Fornari, Franco. The Psychoanalysis of War, translated by Alenka Pfeiffer. Bloomington and London: Indiana University Press, 1975.

Frazer, James. The Golden Bough: A Study in Magic and Religion. $3^{\text {rd }}$ edn. 12 vols. London: Macmillan, 1911-1936.

Freud, Sigmund. Thoughts for the Times on War and Death (1915). In The Standard Edition of the Complete Psychological Works of Sigmund Freud, Vol. XIV (1914-1916), translated and edited by James Strachey, 273-302. London: Hogarth Press and the Institute of Psycho-Analysis, 1957.

Fried, Morton H. "Warfare, Military Organization, and the Evolution of Society." Anthropologica, new series, 3, no. 2 (1961): 134-47.

Geertz, Clifford. The Interpretation of Cultures: Selected Essays. New York: Basic Books, 1973.

Giddens, Anthony. The Constitution of Society: Outline of the Theory of Structuration. Cambridge: Polity, 1984.

—. Modernity and Self-Identity: Self and Society in the Late Modern Age. Cambridge: Polity, 1991.

Ginzburg, Carolo. "Morelli, Freud and Sherlock Holmes: Clues and Scientific Method." History Workshop Journal 9, no. 1 (1980): 5-36.

Good, Edwin M. "Capital Punishment and Its Alternatives in Ancient Near Eastern Law." Stanford Law Review 19, no. 5 (1967): 947-77. 
Grossman, Dave. On Killing: The Psychological Cost of Learning to Kill in War and Society. New York and Boston: Back Bay Books, 1995.

Haas, Jonathon, ed. The Anthropology of War. Cambridge, New York, Melbourne:

Cambridge University Press, 1990.

Hensel, Howard M., ed. The Prism of Just War: Asian and Western Perspectives on the Legitimate Use of Military Force. Farnham, UK and Burlington, VT: Ashgate, 2010.

Hodgson, Marshall. "The interrelations of societies in history." Comparative Studies in Society and History 5, no. 2 (1962/3): 227-50.

Johnson, James Turner. Ideology, Reason, and the Limitation of War: Religious and Secular Concepts 1200-1740. Princeton: Princeton University Press, 1975.

—. Just War Tradition and the Restraint of War. Princeton: Princeton University Press, 1981.

—. The Holy War Idea in Western and Islamic Traditions. University Park, PA: Pennsylvania State University Press, 1997.

—. Ethics and the Use of Force: Just War in Historical Perspective. Farnham, UK and Burlington, VT: Ashgate, 2011.

Johnson, James Turner and John Kelsay, eds. Cross, Crescent, and Sword: The Justification and Limitation of War in Western and Islamic Tradition. New York and London: Greenwood Press, 1990.

Kelsay, John. Islam and War: A Study in Comparative Ethics. Louisville, KY:

Westminster/John Knox Press, 1993.

—. "Islamic tradition and the justice of war." In The Ethics of War in Asian Civilizations: A Comparative Perspective, edited by Torkel Brekke, 81-110. Abingdon and New York: Routledge, 2006.

—. Arguing the Just War in Islam. Cambridge, MA: Harvard University Press, 2007.

—. "Just War, Jihad, and the Study of Comparative Ethics." Ethics and International Affairs 24, no. 3 (2010): 227-38.

Kelsay, John and James Turner Johnson, eds. Just War and Jihad: Historical and Theoretical Perspectives on War and Peace in Western and Islamic Traditions. New York: Greenwood Press, 1991.

Laing, Robert D. The Divided Self: An Existential Study in Sanity and Madness. Repr. Harmondsworth: Pelican, 1965. 
Lane, Frederic C. "Conclusion.” In Enterprise and Social Change: Readings in Economic History, edited by Frederic C. Lane and Jelle C. Riemersma, 522-34. Homewood, IL: Richard D Irwin, 1953.

Lang, Jr., Anthony F. "The Just War Tradition and the Question of Authority.” Journal of Military Ethics 8, no. 3 (2009): 202-16.

Leach, Edmund R. Political Systems of Highland Burma: A Study of Kachin Social Structure. repr. London and Atlantic Highlands, NJ: Athlone Press, 1993.

Lebow, Richard Ned. "Fear, interest and honour: outlines of a theory of International Relations." International Affairs, 82, no. 3 (2006): 431-48.

LeShan, Lawrence. The Psychology of War: Comprehending Its Mystique and Its Madness. Chicago: The Noble Press, 1992.

Linklater, Andrew. Violence and Civilization in the Western States Systems. Cambridge: Cambridge University Press, 2017.

Lo, Ping Cheung, ed. Chinese Just War Ethics: Origin, Development, and Dissent. London: Routledge, 2015.

Mitzen, Jennifer. "Ontological Security in World Politics: State Identity and the Security Dilemma.” European Journal of International Relations 12, no. 3 (2006): 341-70.

Morkevicius, Valerie. "Ethics of War in Protestant Christianity." In World Religions and Norms of War, edited by Gregory M. Reichberg, Vesselin Popovski, and Nicholas Turner, 220-54. Tokyo: United Nations University Press, 2009.

Muchembled, Robert. A History of Violence: from the End of the Middle Ages to the Present. Cambridge: Polity, 2012.

Nardin, Terry. "Introduction.” In The Ethics of War and Peace: Religious and Secular Perspectives, edited by Terry Nardin, 3-12. Princeton: Princeton University Press, 1996.

O’Driscoll, Cian. "Rewriting the Just War Tradition: Just War in Classical Greek Political Thought and Practice.” International Studies Quarterly 59, no. 1 (2015): 1-10.

O'Driscoll, Cian and Daniel Brunstetter, eds. Just War Thinkers: from Cicero to the $21^{\text {st }}$ Century. London and New York: Routledge, 2018.

Perry, William J. Children of the Sun: A Study of the Egyptian Settlement of the Pacific. London, 1923.

—. The Growth of Civilization. London: Methuen \& Co, 1924

Pfanz, Harry W. Gettysburg: The Second Day. Chapel Hill: The University of North Carolina Press, 1987. 
Pinker, Steven. The Better Angels of Our Nature: A History of Violence and Humanity. London: Penguin, 2011.

Pitt, David C. Using Historical Sources in Anthropology and Sociology. New York: Holt, Rinehart and Winston, 1972.

Ranke, Leopold von. The Theory and Practice of History, edited and translated by Georg G. Iggers, Konrad von Moltke, and Wilma A. Iggers. London: Routledge, 2011.

Reichberg, Gregory M., Henrik Syse, and Endre Begby, eds. The Ethics of War: Classic and Contemporary Readings. Malden, MA and Oxford: Blackwell, 2006.

Reichberg, Gregory M. and Henrik Syse, eds. Religion, War, and Ethics: A Sourcebook of Textual Traditions. New York: Cambridge University Press, 2014.

Russell, Frederick H. The Just War in the Middle Ages. Cambridge: Cambridge University Press, 1975.

Sewelll, Jr., William H. "Marc Bloch and the Logic of Comparative History." History and Theory 6, no. 2 (1967): 208-18.

Shakespeare, William. The Life of Henry the Fifth. In The Oxford Shakespeare: The Complete Works, edited by Stanley Wells, Gary Taylor, et al. Oxford: Oxford University Press, 1994.

Simiand, François. "Méthode historique et science sociale." Revue de synthèse historique 6 (1903): 154-157.

_. "Causal Interpretation and Historical Research.” In Enterprise and Social Change: Readings in Economic History, edited by Frederic C. Lane and Jelle C. Riemersma, 469-93. Homewood, IL: Richard D Irwin, 1953.

Simpson, Anthony. "Freud on the State, Violence, and War." Diacritics 35, no. 3 (2005): 7891.

Skinner, Quentin. "Meaning and Understanding in the History of Ideas." History and Theory 8 (1969): 3-53; revised in Skinner, Quentin. Visions of Politics. 3 vols., vol. 1, 57-89. Cambridge: Cambridge University Press, 2002.

Smelser, Neil J. Comparative Methods in the Social Sciences. Eaglewood Cliffs, NJ: Prentice-Hall, 1976.

Smith, G. Elliot. The Diffusion of Culture. London: Watts, 1933.

Sorabji, Richard and David Rodin. "Introduction." In The Ethics of War: Shared Problems in Different Traditions, edited by Richard Sorabji and David Rodin, 1-9. Aldershot: Ashgate, 2006. 
Speier, Hans. "Class Structure and 'Total War'." American Sociological Review 4, no. 3 (1939): 370-80.

Steele, Brent. Ontological Security in International Relations: Self-Identity and the IR State. London and New York: Routledge, 2008.

Stewart, George R. Pickett's Charge: A Microhistory of the Final Attack at Gettysburg, July 3, 1863. Boston: Houghton Mifflin Company, 1959.

Syse, Henrik. "The Platonic Roots of Just War Doctrine: A Reading of Plato's Republic." Diametros 23 (2010): 104-23.

Syse, Henrik and Gregory M. Reichberg, eds. Ethics, Nationalism, and Just War: Medieval and Contemporary Perspectives. Washington, D. C.: Catholic University of America Press, 2007.

Thucydides. History of the Peloponnesian War, translated by Rex Warner, introduction and notes by M. I. Finley. Harmondsworth: Penguin, 1954.

Vayda, Andrew. "Expansion and Warfare among Swidden Agriculturalists." In Environment and Cultural Behaviour: Ecological Studies in Anthropology, edited by Andrew Vayda, 202-20. Garden City, NY: Natural History Press, 1969

Walker, Philip L. “A Bioarchaeological Perspective on the History of Violence.” Annual Review of Anthropology 30 (2001): 573-96.

Walzer, Michael. Just and Unjust Wars: A Moral Argument with Historical Illustrations. $4^{\text {th }}$ edn. New York: Basic Books, 2006.

Weber, Max. “'Objectivity' in Social Science.” In Weber, Max. The Methodology of the Social Sciences, translated and edited by Edward A. Shils and Henry A. Finch, 50-112. New York: The Free Press, 1949.

_. From Max Weber: Essays in Sociology, translated and edited, with an introduction, by H. H. Gerth and C. Wright Mills. London: Routledge, 2009.

Weil, Simone. Simone Weil's The "Iliad" or The Poem of Force: A Critical Edition, edited and translated by James P. Holoka. New York: Peter Lang, 2003.

Wickham, Chris. "Problems in Doing Comparative History." In Challenging the Boundaries of Medieval History: The Legacy of Timothy Reuter, edited by Patricia Skinner, 5-28. Turnhout: Brepols, 2009.

Williams, Bernard. "In the Beginning was the Deed." In In the Beginning was the Deed: Realism and Moralism in Political Argument, edited by Geoffrey Hawthorne, 18-28. Princeton: Princeton University Press, 2005.

Wright, Quincy. A Study of War. $2^{\text {nd }}$ edn. 2 vols. Chicago: University of Chicago Press, 1965. 
${ }^{1}$ The literature on violence is too vast to list here, but some attempts to trace a history of violence include: Walker, "A Bioarchaeological Perspective on the History of Violence"; Brown, Violence in Medieval Europe; Pinker, The Better Angels of Our Nature; Muchembled, A History of Violence. For a sociological and normative IR theory approach, see Linklater, Violence and Civilization in the Western States Systems.

2 See also Lane, "Conclusion," 523.

${ }^{3}$ See indicative essays: Ranke, The Theory and Practice of History; Simiand, "Méthode historique et science sociale," 154-157; idem, "Causal Interpretation and Historical Research," 469-93.

${ }^{4}$ Walzer, Just and Unjust Wars; Coates, The Ethics of War.

${ }^{5}$ Russell, The Just War in the Middle Ages; Johnson, Ideology, Reason, and the Limitation of War: Religious and Secular Concepts 1200-1740; idem, Just War Tradition and the Restraint of War; idem, The Holy War Idea in Western and Islamic Traditions; idem, Ethics and the Use of Force: Just War in Historical Perspective; Johnson and Kelsay, eds., Cross, Crescent, and Sword; Kelsay, Islam and War; idem, "Islamic tradition and the justice of war"; 2006, 81-110; idem, Arguing the Just War in Islam; idem, "Just War, Jihad, and the Study of Comparative Ethics"; Kelsay and Johnson, eds., Just War and Jihad.

${ }^{6}$ An indicative list includes: Bellamy, Just Wars; Brekke, ed., The Ethics of War in Asian Civilizations; Reichberg, Syse, and Begby, eds., The Ethics of War; Syse and Reichberg, eds., Ethics, Nationalism, and Just War; Bonner, Jihad in Islamic History; Lang, "The Just War Tradition and the Question of Authority"; Morkevicius, "Ethics of War in Protestant Christianity"; Hensel, ed., The Prism of Just War; Syse, "The Platonic Roots of Just War Doctrine: A Reading of Plato's Republic"; Reichberg and Syse, eds., Religion, War, and Ethics; Lo, ed., Chinese Just War Ethics; O’Driscoll, "Rewriting the Just War Tradition: Just War in Classical Greek Political Thought and Practice"; Cox, "Expanding the History of the Just War: The Ethics of War in Ancient Egypt”; idem, "The Ethics of War up to Thomas Aquinas"; O’Driscoll and Brunstetter, eds., Just War Thinkers.

${ }^{7}$ Bloch, "Toward a Comparative History of European Societies," 496.

${ }^{8}$ Bloch, "Toward a Comparative History of European Societies," 494-6.

${ }^{9}$ Stewart, Pickett's Charge; Pfanz, Gettysburg: The Second Day.

${ }^{10}$ Bloch, "Toward a Comparative History of European Societies," 496.

${ }^{11}$ Bloch, "Toward a Comparative History of European Societies," 496-8.

12 Sewelll, "Marc Bloch and the Logic of Comparative History," 215.

${ }^{13}$ Freud, The Standard Edition of the Complete Psychological Works of Sigmund Freud, Vol. XIV (1914-1916), 299.

${ }^{14}$ Bloch, "Comparative History", 507.

${ }^{15}$ Geertz, The Interpretation of Cultures, 43. Compare Durkheim's statement that: 'Comparative sociology is not a particular branch of sociology; it is sociology itself, in so far as it ceases to be purely descriptive and aspires to account for facts.' Durkheim, The Division of Labor in Society, 139. Also cited in Smelser, Comparative Methods in the Social Sciences, 2.

${ }^{16}$ Wickham, "Problems in Doing Comparative History," 6-7.

${ }^{17}$ Smelser, Comparative Methods, 1.

${ }^{18}$ Bloch, "Comparative History", 497-8. 
${ }^{19}$ Even Bloch was ready to admit that: 'A general phenomenon must have equally general causes.' Bloch, “Comparative History," 505.

${ }^{20}$ Sorabji and Rodin. "Introduction," 2.

${ }^{21}$ Bloch, "Comparative History”, 501-2.

${ }^{22}$ On inter-regional continuity and supra-national societies, see Hodgson, "The interrelations of societies in history", 227-50.

${ }^{23}$ This question hinges on providing a historical context for ethical reflection or legal developments. As

Bederman observes: 'It is not enough...that States may have said that they observed a particular rule of international law. It is quite another matter to see whether they, in fact, did so.' Bederman, International Law in Antiquity, 5.

${ }^{24}$ Williams, "In the Beginning was the Deed".

${ }^{25}$ Freud, Complete Works, vol. 14: 292-4; see also Simpson, "Freud on the State, Violence, and War," 86.

${ }^{26}$ Good, "Capital Punishment and Its Alternatives in Ancient Near Eastern Law," 947-77; Grossman, On Killing.

${ }^{27}$ Haas, ed., The Anthropology of War, p. xiii; Fried, "Warfare, Military Organization, and the Evolution of Society," 134-5.

${ }^{28}$ Pitt, Using Historical Sources in Anthropology and Sociology, 7; Ferguson, "Explaining War,” 29. For an attempted synthesis of a functionalist and historically-sympathetic approach, see Leach, Political Systems of Highland Burma, $281 \mathrm{ff}$.

29 Andreski, Military Organization and Society, 7.

${ }^{30}$ For examples of this materialist argument, see: Vayda, "Expansion and Warfare among Swidden Agriculturalists," 202-20; Leach, Political Systems of Highland Burma, 10; Andreski, Military Organization and Society, 10; Fried, "Military Organization," 139. For a more nuanced view, see Ferguson, "Explaining War," 29-32.

31 Thucydides, History of the Peloponnesian War, Bk. V, 400-8.

32 The beginning of such work, as well as numerous examples of warriors having to fulfil taboo obligations and purification rituals, can be found in Frazer, The Golden Bough, vol. 4, 157-90.

${ }^{33}$ See Crawford, "The Passion of World Politics: Propositions on Emotion and Emotional Relationships," 11656; idem, "Emotions and international security: Cave! Hic Libido," 121-3; idem, "Institutionalizing Passion in World Politics: Fear and Empathy," 535-57; Lebow, "Fear, interest and honour: outlines of a theory of International Relations," 431-48.

${ }^{34}$ Ferguson, "Explaining War", 33-4.

${ }^{35}$ Ferguson, "Explaining War", 43.

${ }^{36}$ The most dedicated advocates of diffusionist theory included Perry, Children of the Sun; idem, The Growth of Civilization; Smith, The Diffusion of Culture, esp. 208-32.

${ }^{37}$ Geertz, Interpretation of Cultures, 5.

38 'The fact is that to commit oneself to a semiotic concept of culture and an interpretive approach to the study of it is to commit oneself to a view of ethnographic assertion as, to borrow W. B. Gallie's by now famous phrase, "essentially contestable." Anthropology, or at least interpretive anthropology, is a science whose 
progress is marked less by a perfection of consensus than by a refinement of debate. What gets better is the precision with which we vex each other.' Geertz, Interpretation of Cultures, 29.

${ }^{39}$ Ginzburg, "Morelli, Freud and Sherlock Holmes: Clues and Scientific Method," 11.

${ }^{40}$ For the classical statement of this approach, see Skinner, "Meaning and Understanding in the History of Ideas".

${ }^{41}$ Geertz, Interpretation of Cultures, 15.

${ }^{42}$ Geertz, Interpretation of Cultures, 17-18.

${ }^{43}$ Geertz, Interpretation of Cultures, 44.

${ }^{44}$ Speier, "Class Structure and 'Total War'," 370.

${ }^{45}$ Wright, A Study of War, vol. 1, 434; vol. 2, 705.

${ }^{46}$ Clausewitz, On War, Bk. I.1.2, 75.

${ }^{47}$ Durkheim, Rules of Sociological Method, 35, 43, 59.

${ }^{48}$ Durkheim, Rules of Sociological Method, 39-40.

${ }^{49}$ Durkheim, Rules of Sociological Method, 40, 45.

${ }^{50}$ Durkheim, Rules of Sociological Method, 46.

${ }^{51}$ Smelser, Comparative Methods, 48.

${ }^{52}$ Smelser, Comparative Methods, 44, 51; Durkheim, Sociological Method, 62-3.

${ }^{53}$ Weber, “'Objectivity' in Social Science,” 54.

${ }^{54}$ Nardin, "Introduction," 9.

${ }^{55}$ Weber's definition of an ideal type: 'The ideal typical concept will help to develop our skill in imputation in research: it is no "hypothesis" but it offers guidance to the construction of hypotheses. It is not a description of reality but it aims to give unambiguous means of expression to such a description...An ideal type is formed by the one-sided accentuation of one or more points of view and by the synthesis of a great many diffuse, discrete, more or less present and occasionally absent concrete individual phenomena, which are arranged according to those one-sidedly emphasized viewpoints into a unified analytical construct (Gedankenbild). In its conceptual purity, this mental construct (Gedankenbild) cannot be found empirically anywhere in reality. It is a utopia.

Historical research faces the task of determining in each individual case, the extent to which this ideal-construct approximates to or diverges from reality'. Weber, “'Objectivity' in Social Science,” 90.

${ }^{56}$ See above, note 5. See also Cox, "Gratian".

${ }^{57}$ Cox, "Expanding the History of the Just War Tradition", 372.

${ }^{58}$ Wright, Study of War, vol. 2, 683.

${ }^{59}$ For examples and discussion, see Wright, Study of War, vol. 1, 425ff.

${ }^{60}$ Weil, Simone Weil's The "Iliad" or The Poem of Force.

${ }^{61}$ Most anthropologists have abandoned 'instinct' theories, and stress that violence is a learned, cultural behaviour and culture cannot be genetically transmitted: LeShan, The Psychology of War, 15.

${ }^{62}$ See Fornari, The Psychoanalysis of War, p. xxiii.

${ }^{63}$ Fornari, Psychoanalysis of War, p. xv-xvi.

${ }^{64}$ Fornari, Psychoanalysis of War, p. xvi.

${ }^{65}$ Fornari, Psychoanalysis of War, pp. xvii-xviii.

${ }^{66}$ LeShan, Psychology of War, 5, 22. 
${ }^{67}$ LeShan, The Psychology of War, 27-8.

${ }^{68}$ LeShan, The Psychology of War, 117.

${ }^{69}$ LeShan, The Psychology of War, 124.

${ }^{70}$ Shakespeare, The Life of Henry the Fifth, Act 4, scene 1, 585.

${ }^{71}$ In a speech given in 1918, just a few years after Freud's essay on the First World War, Weber also famously defined the state according to its monopolization of violence. See Weber, From Max Weber, 78.

${ }^{72}$ Freud, Complete Works, vol. 14, 279.

${ }^{73}$ Freud, Complete Works, vol. 14, 280.

${ }^{74}$ Laing, The Divided Self, 39-45. Giddens adapts the concept of ontological security into a structural sociological thesis: Giddens, The Constitution of Society; idem. Modernity and Self-Identity. Giddens' work has had a marked and growing influence within the field of security and IR studies, for example see: Mitzen, "Ontological Security in World Politics: State Identity and the Security Dilemma"; Steele, Ontological Security in International Relations. There has also been a spate of journal special issues dedicated to ontological (in)security: Special Issue of Cooperation and Conflict 52, no. 1 (2017); European Security 27, no. 3 (2018); Journal of International Relations and Development (2018) [issue currently unassigned].

${ }^{75}$ Fornari, Psychoanalysis of War, 22-3.

${ }^{76}$ Fornari, Psychoanalysis of War, 32-4.

${ }^{77}$ Freud argues that powerful prohibitions are only laid on powerful impulses: 'What no human soul desires stands in no need of prohibition; it is excluded automatically. The very emphasis laid on the commandment "Thou shalt not kill" makes it certain that we spring from an endless series of generations of murderers, who had the lust for killing in their blood, as, perhaps, we ourselves have to-day.' Freud, Complete Works, vol. 14, 296. ${ }^{78}$ Freud, Complete Works, vol. 14, 283-6, 299. See also Simpson, "Freud on the State", 83.

79 'Thus the transformation of instinct, on which our susceptibility to culture is based, may also be permanently or temporarily undone by the impacts of life. The influences of war are undoubtedly among the forces that can bring about such involution'. Freud, Complete Works, vol. 14, 286.

${ }^{80}$ Davis, "Introduction: Comparative Ethics and the Crucible of War," 1.

${ }^{81}$ Davis, "Introduction: Comparative Ethics and the Crucible of War," 15. 